https://helda.helsinki.fi

Time cycles of homicide in the early modern Nordic area

\author{
Kivivuori, Janne
}

2020-07

Kivivuori , J , Lehti , M , Rautelin , M , Lindström , D \& Netterstrøm , J B 2020 , ' Time cycles

of homicide in the early modern Nordic area ' , Nordic Journal of Criminology, vol. 21 , no. 2 , pp. 152-169 . https://doi.org/10.1080/2578983X.2020.1766283

http://hdl.handle.net/10138/336523

https://doi.org/10.1080/2578983X.2020.1766283

unspecified

acceptedVersion

Downloaded from Helda, University of Helsinki institutional repository.

This is an electronic reprint of the original article.

This reprint may differ from the original in pagination and typographic detail.

Please cite the original version. 


\title{
Time cycles of homicide in the early modern Nordic area
}

\author{
Janne Kivivuori* ${ }^{a *}$ \\ Martti Lehti ${ }^{b}$ \\ Mona Rautelin ${ }^{\mathrm{c}}$ \\ Dag Lindström ${ }^{\mathrm{d}}$ \\ Jeppe Büchert Netterstrøm ${ }^{\mathrm{e}}$
}

a Professor of Criminology, Institute of Criminology and Legal Policy, University of Helsinki, Helsinki, Finland

b Senior Researcher, Institute of Criminology and Legal Policy, University of Helsinki, Helsinki, Finland

c Project Researcher, Department of History and Ethnology, University of Jyväskylä, Jyväskylä, Finland

d Professor of History, Department of History, University of Uppsala, Uppsala, Sweden

e Associate Professor of History, Department of History, University of Aarhus, Aarhus, Denmark

*Corresponding author

Janne Kivivuori

Professor of Criminology

University of Helsinki

Unioninkatu 40

00014 Helsinki

janne.kivivuori@helsinki.fi

\section{Acknowledgements}

This research was funded by the Scandinavian Research Council for Criminology. We thank all the members and partners of the Nordic Homicide from Past to Present research project. Thanks also to research assistants Maiju Tanskanen, Minna Mannila, Anna Raeste and Joona Mäkelä as well as Ian R. Dobson for language inspection. Professor Petri Karonen and Adjunct 
Professor Anu Koskivirta have given valuable comments and feedback on earlier versions of this manuscript.

\section{Funding details}

This work was supported by the Scandinavian Research Council for Criminology under Grant Number 20180044. 


\title{
Time cycles of homicide in the early modern Nordic area
}

\begin{abstract}
An extensive body of criminological research has shown that criminal and violent behaviour manifests time patterns in terms of daily, weekly and annual cycles. This is consistent with criminological routine activities theory. Can we generalize these patterns to historical periods? In this article, we draw on a recently created unique dataset, covering the years 1608 to 1699 in three Nordic regions, to explore time cycles of offending in the early modern period. Examining daily, weekly and annual cycles, we find that lethal violence manifested strong time patterns in the early modern period. The role of public holidays was central especially in the period lasting from Christmas to Midsummer. Probing the role of key routines, we disaggregated the composition of homicide cycles by alcohol use and place of occurrence. The findings indicated that early modern homicide time cycles were associated with alcohol use and activities in private places. We conclude by discussing the strengths and limitations of our data and by suggesting further research in the promising frontier of standardized long duration homicide research.
\end{abstract}

Keywords: Homicide; criminology, history, time cycles, Nordic countries 


\section{Time cycles of homicide in the early modern Nordic area}

The study of seasonal patterns of crime started in criminology soon after administrative statistics were created in the 1820 s, as magnificently shown by Quetelet's Recherches sur le penchant au crime aux différens ages (Quetelet 1831, pp. 51-53). Since then, a rich body of research has described time patterns of crime in modern societies, using the data resources available in modern criminology. Yet, we do not know whether and how crime manifested seasonal and other cyclical patterns before the post-1820s 'avalanche of numbers' reflecting the powers of the modern state. There is a scarcity of systematic evidence going further back in time to the pre-statistics era. In this article, we took up the challenge of expanding criminology's analytical gaze on the deeper past in the early modern age. We did this by studying if homicide manifested recurring time patterns in the Nordic area during the $17^{\text {th }}$ century.

While describing the patterns, we also linked the findings to theoretical concerns of criminology. Criminological routine activity theory predicts that crime risks are not random in time. Rather, they manifest meaningful links to daily, weekly and annual cycles of human life (Felson \& Eckert 2016). Modern crime data consistently show relations between socially constituted time cycles and patterns of crime. We know that modern homicide is not evenly spread nor randomly occurring with respect to the day, week or year (Lehti et al. 2019). From the point of view of routine activity theory, cycles of criminal activity reflect the recurring features of everyday life. Illegal behaviours follow the rhythms of routines, which in themselves are not against the law, such as the cycles of work and leisure, patterns of entertainment and moving through public space. Other relevant factors causing time patterns include cultural or legal conventions and human universals as well as geographic and climate-related factors. From this theoretical point of view, there is reason to expect that pre-modern patterns of crime were also embedded in the routine activities of the age.

\section{Theoretical background}

Routine activity theory is one of the most general criminological theories of crime. As such, it ought to apply to all historical periods, but hitherto it has mainly been applied to modern data. According to the theory, crime happens when motivated offenders and suitable targets coincide in the absence of capable guardians (Cohen \& Felson 1979; Felson \& Eckert 2016). A fundamental aspect is that crime rates and crime patterns emanate from the flow of routines in 
normal practices and routines in time and space. The theory predicts that crime is patterned in time reflecting routine cycles of society (Felson \& Eckert 2016). If, for instance, Sunday is the only holiday in a week, alcohol and leisure related criminal offences tend to be concentrated to Sundays. Again, if the weekend extends to Saturdays as well, criminal offences are predicted to spread to Saturdays, even reducing the proportion of offences committed on Sundays (Kivivuori 2003).

Long-term analysis of time cycles is a potentially rewarding research frontier because routine activities are not permanent by nature. Changes can be either slow or fast. For example, in the early modern age the rise of civility (Elias 2017 [1939]) as a social ideal correlated with several slowly unfolding structural-cultural changes in everyday routine activities, possibly influencing the rates and characteristics of lethal violence (Eisner 2014; Thomas 2018; Tickell 2018). On the other hand, routine activity theory also accommodates and predicts more abrupt changes, that is, short and middle term shocks. This refers especially to short-term crime peaks, when temporally more time-fixed and specific ruptures in mass routine actions take place, such as during societal disruptions caused by a famine or military demobilization (Gurr 1981; Lockwood 2017). Both sudden routine activity shocks and the slow change in social structures can influence the patterning of crime in the space-time grid.

\section{Prior research}

Empirical work on homicide time cycles of early modern Europe is scarce. To study them is quite challenging because of the scarcity and the qualitative form of the available sources. Furthermore, the notion of time itself can change over the long duration. In the early modern period, time was a relative term, and in many respects taken for granted, resulting in missing data in the sources. It is therefore often difficult to establish any time cycles of homicide offending from early modern court protocols. ${ }^{1}$

In the Nordic countries, the present study is the first regional comparative study of $17^{\text {th }}$ century homicide time cycles. For the $18^{\text {th }}$ century (Koskivirta $2001 ; 2003$ ) and $19^{\text {th }}$ century (Ylikangas 1998, orig. 1976; Rajala 2004), a few national studies exist. The data from these studies stem from predominantly agrarian and rural societies, and therefore provide good comparative material for the results and analyses of our study. The study by Koskivirta (2001, 377-378) included information about the monthly and seasonal cycles of homicides in Eastern Finland in 1748-1807. The studies of Ylikangas and Rajala also described the weekly and daily 
cycles. Ylikangas (1998) examined homicides of Southern Ostrobothnia in 1790-1825, while Rajala's (2004) study was about lethal violence in the Karelian Isthmus during the period 18851917.

In Eastern Finland in the second half of the $18^{\text {th }}$ century, winter was the most violent season and autumn the least violent. During the period, 56 per cent of the homicides in the Savo-Karelian province took place between the beginning of December and the end of May. This figure indicates a six-percentage points 'surplus' of violence (when compared to a hypothetical even-monthly distribution of homicides) during that time interval. According to Koskivirta, the seasonal cycle was connected to the economic cycle of local agriculture, and high consumption of alcohol during the All Saints' Day, Christmas and other annual holidays. However, also other factors seem to have played a role. For instance, murders increased in May and September when the local circuit court had its bi-annual sessions. The victims of these murders were persons summoned to the courts as witnesses (Koskivirta 2001, pp. 377-378). While this finding testifies to a counter-productive effect of law sessions, it also shows how violence stems from lawful routine activities.

In the Southern Ostrobothnia of the early $19^{\text {th }}$ century, the monthly numbers of homicides peaked in late autumn and winter. Spring and early summer were the least violent months. Ylikangas explains this type of the annual cycle with fluctuations in the availability of alcohol for consumption and in the monthly incomes of casual farm labourers (Ylikangas 1998, pp. 47-48). The situation in the Karelian Isthmus in the last few decades of the $19^{\text {th }}$ century was different, as was the economic setting. Agriculture was still the main livelihood but both forest industry and the summer villa settlements of the Sankt Petersburg bourgeoisie had a substantial role in the local economy and its cycles. The peak season for lethal violence in this region occurred during the summer, lasting from May to September, coinciding with the holiday villa season with a lively nightlife (Rajala 2004, pp. 105-106). This monthly cycle resembles the situation in Finnish cities during the first three decades of the $20^{\text {th }}$ century. However, the seasonal homicide cycle in rural parishes in the early $20^{\text {th }}$ century Finland was still the same as in early $19^{\text {th }}$ century Ostrobothnia with most of the crimes taking place in the second half of the year (Lehti 2001, pp. 72-73).

In the Southern Ostrobothnia of the early $19^{\text {th }}$ century, 49 per cent of homicides were perpetrated on Sundays and Mondays. There, the weekly cycle of leisure time and alcohol consumption explained this homicide cycle (Ylikangas 1998, pp. 46-51). The situation was similar in the Karelian Isthmus in the last few decades of the century, making Sunday the most violent day of the week, and Monday the second most violent. Arrests due to public 
drunkenness followed an identical cycle (Rajala 2004, pp. 106-108). This weekly cycle of homicides did not change much in the next few decades, Sunday also being the peak day of violence in Finland in the 1910s, the 1920s and the 1930s (Lehti 2001, pp. 84-85).

Rajala (2004, p. 109) analysed the daily cycle of homicides in the late $19^{\text {th }}$ century Karelia. Three-quarters ( $75 \%$ ) of the homicides took place between $6 \mathrm{pm}$ and $6 \mathrm{am}$. He explains the cycle by the rhythm of the daily consumption of alcohol. This pattern was still evident in the early decades of the next century. In Finland of the 1920s, the corresponding percentage was 80 per cent (Lehti 2001, pp. 87-88). Taken together, prior historical research indicates both familiar cycles and deviations from expected patterns.

\section{Data}

Our data cover three Nordic regions: North-Western Denmark (Northern Jutland), SouthEastern Sweden and Northern Finland. The data were derived from hand-written textual information in original $17^{\text {th }}$ century court protocols. For the analyses, we transformed the qualitative textual data into a quantitative standardized matrix. The process of transforming qualitative information to quantitative form was based on the Historical Homicide Monitor (HHM), which has been developed for the specific purpose of long-duration homicide research (Kivivuori et al. 2020). The data were sampled and coded by professional historians with extensive experience in reading hand-written records in original languages. ${ }^{2}$ While the resulting data are quantitative, we illustrated the nature of lethal conflicts with selected short qualitative case descriptions highlighting aspects with relevance to our interpretation of quantitative findings.

We defined homicide using six behavioural criteria (Kivivuori et al. 2020, pp. 10-13). First, our focal point was violence with lethal outcome, excluding all forms of non-lethal violence, for example incidents legally labelled as 'attempted homicide' in many modern jurisdictions. Second, the act of violence had to be intentional, while the lethal outcome could be unintended by the offender. Some modern jurisdictions employ legal labels such as 'assault and causing of death' in cases where the offender could not foresee that his/her violence could or would result in death. Third, there had to be a direct or indirect cause of death due to physical contact. ${ }^{3}$ Fourth, the person killed must have been born alive. In historical periods, some cases which today would qualify as abortions, were treated under homicide-related legal labels. Fifth, death had to happen within 12 months of the violent act. This time limit was a pragmatic cut- 
off point. In historical data, the time interval between violence and death can be long. It was therefore necessary to define an upper limit. Sixth, killing of fugitives and outlaws was only included if they were being dealt with as a suspected criminal homicide.

Our research includes all homicide types, victims and offenders. However, we excluded infanticide, defined as cases in which the victim was less than one year old. ${ }^{4}$ The decades studied varied by country. For Denmark, the data covered the years from 1608 to 1622 . The main data sources were the verdict books of the high court of Northern Jutland. The Swedish data were from the archive of Göta High Court (the only high court archive of the $17^{\text {th }}$ century fully preserved), covering homicide cases in the period 1640-1650. Unlike Denmark and Sweden, the Finnish data derived from the first instance rural or city circuit courts of Ostrobothnia in 1640-1699, including Kainuu and the southern parts of Lapland, as well as the most northern part of Karelia.

The data included information 543 homicide incidents with 562 victims. All time cycle analyses are drawn from incidents data (192 in Denmark, 158 in Sweden, and 193 in Finland). We studied the daily, weekly and monthly (seasonal) timing of homicides as revealed in the court protocols. ${ }^{5}$ The original sources were hand-written texts depicting the proceedings. The sources did not always contain exact information about when the homicide was committed. Depending on the variable, the percentage of missing data ranged from 18 to 53. All findings reported here are based on known values. We explore this important caveat in detail below, in the "Strengths and limitations" section.

\section{Findings}

\section{Daily cycle}

Evening hours emerged as the most prevalent time for homicide (Table 1). Of all incidents in our data, nearly half (47\%) took place between $6 \mathrm{pm}$ and $12 \mathrm{pm}$. Night and morning were correspondingly the least likely times for lethal violence. ${ }^{6}$

When we compared the three regions, some differences emerged. In Denmark and Sweden, the evening peak was strong, but otherwise the cycles differed. While the night was relatively violent in Denmark, morning had the second highest homicide levels in Sweden. Finland diverged from the two other countries with a less pronounced evening peak and high homicide levels in the afternoons. 
[Insert Table 1 here]

In all three countries, the comparatively low proportion of homicides taking place at night could be explained by specific routine activity and cultural factors. Before the introduction of street lightning, movement outside buildings at night was challenging. Furthermore, fear of the night was common due to beliefs in ghosts and witches, deterring people from movement after dusk (Duedahl and Langen 2015). The relative lack of homicide at night could also reflect effective deterrence. At least in the early $17^{\text {th }}$ century Denmark, it was seen as an aggravating circumstance if a crime was committed after sunset, because it was viewed as cowardly behaviour to attack someone in the darkness of night. The effect of this transgressed legal stipulations, if notions of honourable behaviour discouraged homicide by stealth; honourable men were expected to fight openly and on equal terms (Liliequist 2009; Netterstrøm 2017). Finally, considering that daily social rhythms are partially a function of natural light conditions, light can reflect differences in latitude. The Finnish research area was located approximately one thousand kilometres to the north of the Danish and Swedish areas, which shared the same latitude. In sum, the observed patterns reflect the interaction of legal, cultural and even natural factors.

\section{Weekly cycle}

We observed a clear weekly cycle in early modern homicide. The combined Nordic pattern shows a homicide peak during Sundays, which was the only weekly rest day in societies of the era. One in four cases (23\%) took place on a Sunday (Table 2). Both Denmark and Sweden showed weekly peaks on Sunday. However, in Finland, homicides peaked on Saturdays.

[Insert Table 2 here]

Denmark and Sweden also indicated high relative risk on Mondays and a clearly reduced percentage of homicides on Fridays. In Finland, Sundays were the second most likely weekday for homicide. Indeed, there was a shared pattern in this regard: in all three regions, the day following the peak day was also a relatively high-homicide day. Figure 1 highlights this pattern by showing the weekly cycle in relation to the peak day ${ }^{7}$ separately for the three regions and for the complete data. 
[Insert Figure 1 here]

The Sunday peak reflected leisure day routine activities. The reason why Saturday was the peak time for Finnish homicide is less easy to explain but was probably also related to leisure time patterns. The primary sources showed that church attendance in Northern Finland often included overnight stays with kin living in the church village, while the tradition of joint Saturday bathing included socializing with other villagers and neighbours in the shared village or sauna. Of the Finnish homicides, many were committed in the context of, and proximity to, Sunday church. Even more cases occurred in saunas or their vicinity. Sauna was the focal point for many activities in the household, not only for bathing but also for curing illnesses, giving birth, cleaning bodies for burial or inspections of wounds for prosecution, and for washing clothes as well as kitchen and other utensils. Saunas also functioned as guest rooms, accommodating kin and friends, day workers, travellers and vagrants (Vuorenjuuri 1967).

Although the church and the sauna appear to have been crime attractors in Finland in the early modern age, the true crime generator of homicide offending was the socializing in and around these facilities, sometimes in connection with alcohol consumption. An example was an incident involving two adult married male neighbours, who met up for socializing including food, drinks and the sauna in Southern Ostrobothnia (Ilmajoki 1645). In the sauna, the men started arguing about the neighbour's suspected extramarital affair with the host's unmarried maid, which culminated in a knife fight. A female bystander tried to separate the two fighters but received a lethal wound.

A similar homicide pattern existed in church attendance-related homicides in Denmark, where most Sunday homicides took place in connection with drinking parties after church hours. In one case taking place in the village of Tjæreborg in Southwest Jutland (1617), village people including both genders gathered in a private house after church hours. The participants took turns to buy beer from the host. Suddenly 'words arose' between some of the guests. Frans Ingvorsen complained that Jep Jensen and Thonis Hansen had previously sailed away from him in a boat and left him behind on the island of Fanø outside the mainland, where all three lived. The quarrel escalated into violence resembling a group fight, ending in a stabbing of two of the quarrellers, and the death of Frans Ingvorsen within two days.

The direct connection between church attending and subsequent drinking events was not stated explicitly in this or any other of the Danish cases. As in the other two study regions, alcohol was often present in Sunday homicides (see also Table 5 below). Alcohol was most probably a factor in many of the other Sunday killings, even if not explicitly mentioned. In 
many of the alcohol related cases on Sundays, the sources give detailed accounts that the homicide happened while offender and victim were partying together. Most of the Sunday homicides, where alcohol was involved, took place in the evening after church, and none in the morning before church. Not everybody attended church each week, and not all participants in lethal Sunday parties necessarily came from church. After all, Sunday was the only day of rest, affecting the routine activities related to alcohol consumption.

Sweden also manifested a connection between Sunday homicides and alcohol consumption. Most involved drinking and took place during the evening hours. There were also cases explicitly connected with socializing and drinking after church. In Påboda in 1643, several people were invited to eat and drink when leaving the church. The party continued into the evening and several people got involved in a wrangle during which one of the guests was stabbed. In Almundsryd in 1647, people gathered outside the church after Sunday sermon and beer and spirits were for sale. Two peasants started to quarrel about economic issues. At least one of them was very drunk. Several people got involved and on the way from church, one of the peasants was stabbed to death. In Torsås in 1649, a navy seaman and another man went to the church rectory to drink beer. There was animosity between them because of a debt. They started to fight several times but also continued to drink and smoke tobacco together in other houses before they decided to go back to the church rectory. On the way back, the navy seaman hit the other man in the stomach with an axe.

The relatively high numbers of homicides on Mondays in Denmark and Sweden were not a result of prolonged Sunday parties, extending after midnight, since few homicides were committed during the night between Sundays and Mondays, or on Monday mornings. In Denmark, more than two-thirds of the Monday killings took place in the evening. Possibly some of the homicides happening on Mondays resulted from quarrels initiated during Sunday gatherings, but this does not seem to have been a very pronounced feature, considering the fact that there were as many homicides on Wednesdays as on Mondays in Denmark. ${ }^{8}$ Contrary to this, Sunday was the day after the main partying night in Finland, and as such the second most violent day of the week. However, also in Finland, the crimes of Saturday and Sunday did not form an uninterrupted continuum. Most homicides on Sundays took place in the afternoon and evening after church sermon.

\section{Monthly and seasonal cycles}


Annual cycles reflect a considerable element of natural life, emanating from seasonal change and its impact on people's routine activities in a specific economy affected by the agricultural conditions of the early modern period.

If homicides had been equally distributed throughout the year, each month would include about eight per cent of all homicides. ${ }^{9}$ This is not the case. The number of homicides peaked in April, with 12 per cent of all annual cases (Table 3). Also, May, June, and July showed an above-average proportion of homicide, as well as September and March. To tease out the basic pattern visually, Figure 2 additionally provides a smoothed annual distribution of homicide. It shows a moderate high-homicide period from spring to early summer.

[Insert Figure 2 here]

Table 3 shows the country-specific patterns of monthly distribution. Notable is the Finnish peak in March, the Swedish peak in June, and the Danish in July. In Denmark, the second highest monthly rate of homicide was in May, while in Sweden, the second highest rates were in April and December, and in Finland again in September. The high number of crimes in December in Sweden and in September in Finland could be related to a cluster of public holidays.

[Insert Table 3 here]

We additionally examined annual rhythms of homicide by using a season variable. It contained less missing data than the month variable, because season could also be coded from indirect evidence. The seasonal examination corroborated the spring tilt of early modern Nordic homicides, showing 31 per cent of homicide incidents during the spring months (Table 4). However, the apparent concentration of violence in springtime is largely created by the Finnish data. In Denmark and Sweden, the annual peak covers both spring and summer months more symmetrically.

[Insert Table 4 here]

The seasonality of homicide is itself a historical variable and may change over time due to multiple factors (Tiihonen et al. 1997). Historical research suggests that in early modern Europe, peaking summertime violence was typical in French (places like Castile, Artois) and German regions. Warm weather increased outdoor activities for work or other purposes, which 
brought people together and increased the risk of violent conflict (Ruff 2001, p. 128). The relatively high probability of homicide during the summer months in Denmark and Sweden conform to this pattern. The Finnish curve peaked earlier, in the spring, which could reflect a differential type of agriculture, the slash-and-burn or open frontier economy of Northern Finland (see discussion below).

\section{Public holidays}

Public holidays were intended for religious celebration, but in early modern culture they were also times for feasting and socializing. People came together to sing, dance, talk, court, mate and drink. Some of these popular celebrations were associated with outright excessive and even rebellious behaviour during which norms and hierarchies were put aside. Such public feasts had a potential for violence, because many people gathered under the influence of alcohol, which was consumed in larger quantities than normally. The HHM codebook therefore included a variable to measure whether homicide occurred more frequently on public holidays.

In Denmark, homicides committed on public holidays were, indeed, significantly overrepresented. There, 18 per cent of the homicides were committed on public holidays constituting only 20 days or five per cent of the year. The homicide risk was, thus, three times higher than on ordinary days. In Sweden, 26 per cent of homicides were committed on public holidays. The number of holidays, however, was also higher than in Denmark, 35 days, ten per cent of the year. Thus, also in Sweden, the homicide risk was higher on public holidays, but not as high as in Denmark. In Finland, 24 per cent of the homicides were committed on public holidays ${ }^{10}$.

In all three countries, public holidays clearly raised the homicide risk. In Sweden, homicides peaked at Christmas, Easter, and Midsummer. In Finland, public holiday incidents were similarly concentrated at Easter, and on holidays from December to June. The most dangerous time of the year in Denmark was Pentecost constituting a significant portion of all spring season homicides. The common feature of public holiday incidents in all three countries was a concentration in the period from December to June. In the overall data, 32 per cent of the winter incidents happened during public holidays, while the corresponding proportion was 34 per cent for the spring months. In contrast, the percentage of public holiday offences was lower in the summer $(13 \%)$ and autumn $(3 \%)^{11}$. 
While Easter was a crime generator in all countries, the specific risk holidays otherwise differed within the December-June span. In contrast, autumn homicide stands out as comparatively unrelated to public holidays. Recall that winter comprises the months from December to February.

\section{Alcohol and private place by incident timing}

The time patterns detected in the above analyses were relatively similar in the three countries, with some exceptions like the Finnish Saturday focus, and some differences in relevant specific public holidays. This similarity warranted us to examine selected aspects of homicide without country divisions, by examining whether they change over the time cycles. We decided to explore two aspects connected to routine activities: alcohol use and location of offence. Thus, we explored whether offenders on Sundays were more likely to be under the influence of alcohol during the offence, and whether offences during winter were more likely to take place in private spaces than the average. The last row of Table 5 shows that in our data, 41 per cent of all homicide offenders were under the influence of alcohol, while 49 per cent of all homicide incidents took place in private spaces (mostly private homes ${ }^{12}$ ). Note that the other half of the locations included multiple types of crime places such as agricultural working sites, meadows and streets.

Offenders committing crimes during the evening were more likely to have been under the influence of alcohol in the conflict situation than those killing in other times of the day. Homicides committed during public holidays had more often committed by persons under the influence of alcohol than homicides at other times of the year. Occurrence during the weekend peak, as well as winter and spring homicides manifested an above-average share of offences committed by persons who were under the influence of alcohol during the offence. Note that the weekly peak extended to Monday, which in fact boasted the highest percentage of offenders under the influence of alcohol. Concerning private space as the crime location, we had a replication of the alcohol-related findings. Homicides in private spaces were most pronounced during evenings and weekends. The high proportion of winter homicides perpetrated in private spaces was not surprising in the cold climates of the North.

[Insert Table 5 here] 


\section{Discussion}

In this article, we used unique historical data to describe the time cycles of homicide in the early modern period of three Nordic regions, North-Western Denmark, South-Eastern Sweden, and Northern Finland. In the following discussion, we first sum up our main findings. We then discuss the strengths and limitations of our data sources, and conclude by making some observations regarding future needs for long duration homicide research.

\section{Main findings}

The time cycle types (daily, weekly, monthly, and seasonal) showed both similarities and differences between the three study regions. The daily rhythm of lethal violence peaked in all three regions in the evening, between $6 \mathrm{pm}$ and $12 \mathrm{pm}$. This peak was more pronounced in Denmark and Sweden than in Finland, where afternoons had similar proportions of violence as evenings. The basic pattern of the weekly rhythm was similar in the three countries, with slight deviations in Finland. In Sweden and Denmark, Sunday was the most violent day, while Monday was the second most violent day of the week. In Finland, the peak was on Saturdays, while Sundays showed the second highest rates of homicides. In all three countries, the second most frequent homicide day was the day after the peak.

The seasonal cycle was characterized in all three regions by a relative peak of violence in spring. This is clearer in Finland than in Denmark and Sweden. The month with the highest homicide rate was March in Finland, June in Sweden, and July in Denmark. Thus, the daily, weekly, monthly, and seasonal cycles in Southern Sweden and Western Denmark resembled each other, while Northern Finland diverged from these in some respects. In fact, the Swedish and Danish weekly and daily rhythms resembled more those cycles reported in earlier Finnish studies of the $18^{\text {th }}$ and $19^{\text {th }}$ century than the rhythms documented here. However, the relative spring peak observed in the seasonal cycles of all three regions differed from the situation in $18^{\text {th }}$ and $19^{\text {th }}$ century Finland, where the second half of the year was more violent than the first half (Ylikangas 1998; Rajala 2004; Koskivirta 2001; Lehti 2001).

We also observed whether homicide composition varied as a function of time. For instance, the within-day cycle of homicide showed increasing presence of offender alcohol 
intoxication towards the evening. Similarly, the weekly cycle showed an increasing alcohol presence during the weekend peaks. Homicides on public holidays were closely connected to alcohol use. Evening and weekend homicide also often took place in private places. The observations that weekend and evening homicide was linked to alcohol and private places are interconnected, as people tended to drink alcohol in private homes, which could additionally serve alcohol to outsiders, thus blurring the modern private-public distinction.

\section{Discussion}

The most plausible explanation to the concentration of lethal violence in weekends and evenings is the weekly and daily cycle of leisure time and alcohol consumption. According to earlier studies, this combination guided the rhythm of homicide in agrarian Finland of the $18^{\text {th }}$, $19^{\text {th }}$ and early $20^{\text {th }}$ centuries (Ylikangas 1998; Rajala 2004; Koskivirta 2001; Lehti 2001) and extends to modernity in a true long duration manner (see Lehti \& Sirén 2020 and referred literature). Our analysis corroborates similar factors behind the trends of the $17^{\text {th }}$ century as well. The differences between the regions, and the higher levels of daytime homicide in Finland, could partly be an artefact caused by different main data sources (court protocols from the first legal instance versus high court protocols). Another factor explaining this difference could be the actual structure of violence, i.e. the comparatively higher percentage of domestic violencerelated homicides in Finland.

The spring concentration of lethal violence - common to all three regions in the $17^{\text {th }}$ century Nordic countries - is likely to be a reflection of several factors and their interaction. Our findings show that alcohol was more prominently present in conflicts at this time of year. In mid-winter especially, homicides also concentrated in private places. The role of public holidays appears quite relevant and even drastic, since during the period from December to June, approximately every third homicide occurred on such days, while the corresponding proportion was from zero in Denmark to 10 per cent in Finland through the period from July to November. Such days were more frequent and prominent in the early modern society than they are today. The spring concentration of homicides could be partly be explained by the fact that two important public holidays, Easter and Pentecost, ${ }^{9}$ took place in the spring. However, public holidays can probably not in themselves explain the springtime concentration. More research is needed to examine the role of public holidays in early modern and medieval homicide.

The annual patterns could reflect to the interaction of natural seasonal progression with human routine activities. After the long winter, people increasingly interacted with other people. In the spring, there were many social occasions, such as postponed burials when the 
frost in the ground had melted, or nuptials and christening feasts after church ceremonies (Jutikkala 1958; 1980; Vilkuna 1973; Ylikangas 1998; Rajala 2004). Social interaction with neighbours, acquaintances and friends could have increased the risk of conflicts as well, including those resulting in a lethal outcome. Furthermore, the summer peak may have been attenuated by cold summers, partially linked to the Little Ice Age (Jutikkala 1980; Lappalainen 2012; 2014).

Strain theoretical factors could be also involved in the emergence of time cycle patterns. During the so-called Little Ice Age in the early modern period, food was often scarce in the springtime. When the food stores emptied and people suffered from malnutrition, frustration grew, which could be expressed as an increased propensity for aggressive encounters (Jutikkala 1980; Lappalainen 2012; 2014). The hypoglycaemia caused by malnutrition may also have weakened personal abilities to control any aggressive impulses (Miczek 1994; Koskivirta 2020). Since Northern Finland was the poorest area of the three, the spring strain may have been strongest in this country (Lappalainen 2012; 2014). Some of the Finnish patterns reflect the famine context occurring during the period 1696-98 (Kivivuori et al. unpublished manuscript).

The differences between the three countries are more challenging to tackle than the similarities. Some tentative hypotheses can be offered. The patterns and their divergence in the three countries could be related to the typical economies of the areas, and how they influenced people's routine activities. In the southern village economies (Denmark and Sweden), the open field system of farming meant that agricultural work had to be performed alongside or in cooperation with one's neighbours, as each peasant possessed separate strips of land in the same field (Bjørn 1988). In the northern slash-and-burn and open frontier economy of Northern Finland, families left the village or clusters of frontier farms to cultivate new farmland in the wilderness while living in temporary sheds (Jutikkala 1958; 1980). Consequently, socializing with non-family members or close kin was likely to occur less frequently in the summer months. The comparatively low proportion of summer homicides in Finland could therefore be linked to such economy-based routine activities (Jutikkala 1958; 1980). However, this did not explain why autumn, i.e. harvest time, when neighbours met in the fields, was a time of relatively low homicide rates in Denmark and Sweden.

These findings can be compared with the later situation in $18^{\text {th }}$ century Finland. Koskivirta (2001, pp. 377-378) explains the relatively low level of homicides during harvest, and the high levels later in the autumn and winter, by intensity and type of social interaction. Homicides occurred mainly during leisure times, not during times of intensive work. During 
harvest, men were busy at work and had no time to drink or fight. The conflicts actualized later during the dark winter months, when the agricultural workload was lighter and socializing more intense. The patterns detected here also show the downward trend of homicide towards the late summer harvest season. But we could not detect a 'winter high' in homicide, even though the agricultural cycle was similar.

\section{Strengths and limitations}

In this research, we drew on a database of $17^{\text {th }}$ century homicides which surpasses most other similar prior efforts. In our research era, no police statistics and no court statistics were available. We created the data from original court protocols, written in archaic handwriting and using antiquated linguistic expression. With the emerging data, we were able to conduct unprecedented analyses describing early modern time cycles in homicide, and their links to routine activity related variables, in three regional research sites.

When the early modern courts produced their protocols, they were not aiming to create statistics. Their sole purpose was blame attribution, not causal analysis or social description. This relevance structure poses a major context and limitation for our analysis, as it yields high percentages of missing data for several variables. Exact dates were often missing, and missing data percentages ranged between 18 per cent (season) and 53 per cent (time of day), with month (30\%) and weekday (45\%) showing intermediate shares. In offender alcohol intoxication (15\%) and location (13\%), missing data percentages were lower. Missing data varied across the three study regions. An examination of missing data suggested that the likelihood of missing information does not appear to be systematic in regard to selected control variables. ${ }^{13}$ In any case, the challenge of missing data should be interpreted contextually, and in relation to the existence of alternative information sources and statistics. For our research period, no alternative homicide statistics or any crime statistics were available.

In the early modern era, time of day was not observed in a standardized manner, and time was experienced as a relative phenomenon. Timing information was therefore supplemented by inferring time from explicitly mentioned routine activities, such as sleep or mealtimes. These were more frequent in the Finnish data, reflecting differences between the process in the first instance courts and that in the high courts. The data probably overestimate the proportion of homicides committed during the evening and at night, but less so in Finland than in Denmark and Sweden. Firstly, in many cases the witness testimonies make it clear that the crime was committed during the day, in broad daylight, but not exactly what time of day. 
Timing in these cases was coded as unknown. Secondly, because the commission of crime at night was an aggravating circumstance, the sources reported homicides committed at night more accurately than homicides committed during the day. However, this is unlikely to fully explain the cycle differences between Northern Finland and the two other regions. Finnish homicide was more embedded in familial and kin contexts (Kivivuori et al. unpublished manuscript).

Our data asset represents a new framework, one which expands and can be used to explore multiple topics and theoretical questions (Kivivuori et al. 2020, pp. 16-17). This research of time cycles shows that a standardized analysis of early modern court sources enables the detection of similarities and differences in patterns of homicidal behaviour and suggests avenues for further research. For example, in the future, we will be able to disaggregate the time cycles in terms of other perspectives than routine activity theory, such as strain and gender theories. Furthermore, our findings have theoretical plausibility, as they capture patterns consistent with the routine activity perspective. While criminologists often underscore (with justification) that crime statistics are constructed by control activities, the long-duration stability and interpretability of homicide time cycle patterns challenges this view. The stability and interpretability of time cycles appear to capture real behavioural cycles in the likelihood and patterns of violence.

There is no fundamental obstacle to extending the standardized homicide description to the past, and to forming long-duration data assets such as ours. This analysis has been possible because of the creation of the standardized analytical instrument, the Historical Homicide Monitor (Kivivuori et al. 2020). Researchers using that instrument ensure that their analyses are compatible with the analyses of other researchers anywhere in the world. The new approach thus greatly enhances the capability of researchers to detect both similarities and differences in lethal violence, across places and over time. Indeed, one way to look at this effort is that we are reconstructing crime statistics backwards in time, making distant eras commensurate with one another. 


\section{Literature}

Bjørn, C. (1988). Det danske landbrugs historie (Vols. 1-4). Odense: Landbohistorisk Selskab.

Cohen, L. E. \& Felson, M. (1979). Social Change and Crime Rate Trends: A Routine Activity Approach. American Sociological Review, 44, 588-608.

Duedahl, P. \& Langen, U. (Eds.). (2015). Nattens gerninger. Copenhagen: Gads Forlag.

Elias, N. (2017 [1939]). Über den Prozess der Zivilisation. Soziogenetische und Psychogenetische Untersuchungen. Zweiter Band. Frankfurt: Suhrkamp.

Ellonen, N. \& Kääriäinen, J. \& Lehti, M. \& Aaltonen, M. (2015) Comparing trends in infanticides in 28 countries, 1960-2009. Journal of Scandinavian Studies in Crime Prevention and Criminology, 16(2), 175-193.

Eisner, M. (2014). From Swords to Words: Does Macro-Level Change in Self-Control Predict Long-Term Variation in Levels of Homicide? Crime and Justice, 43, 65-134.

Felson, M. \& Eckert, M. (2016). Crime and Everyday Life. 5th edition. Los Angeles: Sage.

Gurr, T. R. (1981). Historical Trends in Violent Crime: A Critical Review of the Evidence. Crime and Justice, 3, 295-353.

Jackson, M. (2006). Infanticide. The Lancet, 367(9513), 809.

Jutikkala, E. (1958). Suomen talonpojan historia. 2nd edition. Helsinki: SKS.

Jutikkala, E. (1980). Suurten sotien ja uuden asutusekspansion kaudet. In Eino Jutikkala, Yrjö Kaukiainen and Sven-Erik Åström (Eds.), Suomen taloushistoria 1. Agraarinen Suomi (pp. 147-239). Helsinki: Tammi. 
Kivivuori, J. (2003) Sudden Increase of Homicide in Early 1970s Finland. Journal of Scandinavian Studies in Criminology and Crime Prevention, 3(1), 6-21.

Kivivuori, J. \& Rautelin, M. \& Bergsdóttir, G. S. \& Granath S. \& Jónasson, J. O. \& Karonen, P. \& Koskivirta, A. \& Lehti, M. \& Lindström, D. \& Netterstrøm, J. B. \& Okholm, M. (2020). Historical Homicide Monitor 2.0. General instructions and coding manual. Institute of Criminology and Legal Policy, Research Briefs 40/2020. Helsinki: University of Helsinki.

Kivivuori, J. \& Rautelin, M. \& Netterstrøm, J. B. \& Lindström, D. \& Bergsdóttir, G. S. \& Jónasson, J. O. \& Lehti, M. \& Granath, S. \& Okholm, M. \& Karonen, P. \& Koskivirta, A. (Unpublished manuscript). Homicide in Deep Time. Nordic Homicide from Early Modern to Present Era [Working title].

Koskivirta, A. (2001). Sisäinen vihollinen. Henkirikos ja kontrolli Pohjois-Savossa ja Karjalassa Ruotsin vallan ajan viimeisinä vuosikymmeninä. Helsinki: Helsingin yliopisto.

Koskivirta, A. (2003). The Enemy Within. Homicide and Control in Eastern Finland in the Final Years of Swedish Rule 1748-1808. Studia Fennica Historica 5. Helsinki: SKS.

Koskivirta, A. (2020/forthcoming). Rajan lyhenevä varjo? Itäisen Suomen henkirikollisuuden muutos Venäjän ajan alussa. In Piia Einonen \& Miikka Voutilainen (Eds.), Suomen sodan jälkeen. 1800-luvun alun yhteiskuntahistoria. Tampere: Vastapaino.

Kuha, Miia (2014). Rörelse i periferin. Kyrkobesöket i 1600-talets Savolax. In Mats Hallenberg \& Magnus Linnarsson (Eds.). Politiska rum: Kontroll, konflikt och rörelse i det förmoderna Sverige 1300-1850. Nordic Academic Press. pp. 159-173.

Lappalainen, M. (2012). Jumalan vihan ruoska: suuri nälänhätä Suomessa 1695-1697. Helsinki: Siltala.

Lappalainen, M. (2014). Death and Disease during the Great Finnish Famine, 1695-1697. Scandinavian Journal of History, 39(4), 425-447. 
Lehti, M. (2001). Väkivallan hyökyaalto. 1900-luvun alkuvuosikymmenten henkirikollisuus Suomessa ja Luoteis-Virossa. Institute of Criminology and Legal Policy, Research Briefs 178. Helsinki: University of Helsinki.

Lehti, M., Kivivuori, J., Bergsdóttir, G. S., Engvold, H., Granath, S., Jónasson, J. O., Liem, M., Okholm, M., Rautelin, M., Suonpää, K. \& Syversen, V. S. (2019). Nordic Homicide Report. Homicide in Denmark, Finland, Iceland, Norway and Sweden, 2007-2016. Institute of Criminology and Legal Policy, Research Briefs 37/2019. Helsinki: University of Helsinki.

Lehti, M. \& Sirén, R. (2020). The impact of alcohol consumption on homicide: A time-series analysis of three Nordic countries. European Journal of Criminology, 17(3), 352-369.

Liliequist, J. (2009). Ära, dygd och manlighet. Strategier för social prestige i 1600- och 1700talets Sverige. Lychnos: Årsbok för idé- och lärdomshistoria, 117-148.

Lockwood, M. (2017). The Conquest of Death. Violence and the Birth of the Modern English State. Yale: Yale University Press.

Miczek, K. A. (1994). An overview of biological influences on violent behavior. In Albert J. Reiss, Jr., Klaus A. Miczek, and Jeffrey A. Roth (Eds.), Understanding and Preventing Violence, Volume 2: Biobehavioral Influences (pp. 1-21). Washington, DC: The National Academies Press.

Netterstrøm, J. B. (2017). Criminalization of Homicide in Early Modern Denmark (16th 17th Centuries). Scandinavian Journal of History, 42(4), 459-475.

Pihlajamäki, H. (2018). Scandinavian Law in the Early Modern Period. In Heikki Pihlajamäki, Markus D. Dubber, and Mark Godfrey (Eds.): The Oxford Handbook of European Legal History. Oxford University Press. pp. 806-830. DOI:

10.1093/oxfordhb/9780198785521.013.34

Porter, T. \& Gavin, H. (2010). Infanticide and neonaticide: a review of 40 years of research literature on incidence and causes. Trauma, Violence, \& Abuse, 11, 99-112. 
Quetelet, A. (1831). Recherches sur le penchant au crime aux différens ages. Bruxelles: M. Hayez, Imprimeur de l'académie royale.

Rajala, J. (2004). Kurittajia ja puukkosankareita. Väkivalta ja sen kontrollointi Kannaksen rajaseudulla 1885-1917. Helsinki: Suomalaisen Kirjallisuuden Seura.

Rautelin, M. (2009). En förutbestämd sanning : Barnamord och delaktighet i 1700-talets Finland belysta genom kön, kropp och social kontroll. Helsinki: Helsingin yliopisto.

Rautelin, M. (2015). Cryptic Pregnancies and their Legal Consequences in Pre-Modern Finland. Social History of Medicine, 28(4), 663-685.

Thomas, K. (2018). In Pursuit of Civility. Manners and Civilization in Early Modern England. New Haven: Yale University Press.

Tiihonen, J., Räsänen, P. \& Hakko, H. (1997). Seasonal Variation in Occurrence of Homicide in Finland. American Journal of Psychiatry, 154(12), 1711-1714.

Ruff, J. R. (2001). Violence in Early Modern Europe, 1500-1800. Cambridge: Cambridge University Press.

Tickell, S. (2018). Shoplifting in Eighteenth-Century England. Padstow: Boydell Press.

Vilkuna, K. (1973). Vuotuinen ajankierto. 3rd edition. Helsinki: Otava.

Vuorenjuuri, M. (1967). Sauna kautta aikojen. Helsinki: Otava.

Ylikangas, H. (1998). The Knife Fighters. Violent Crime in Southern Ostrobothnia 1790 1825. Annales Academiae Scientificarum Fennicae, Humaniora. Helsinki: Academy of Finnish Science and Letters. Orig. 1976. Puukkojunkkareitten esiinmarssi. Väkivaltarikollisuus Etelä-Pohjanmaalla 1790-1825. Keuruu: Otava. 
Table 1 Homicide incidents by time of day (\%), Nordic countries 1608-1699.

\begin{tabular}{|r|c|c|c|c|}
\hline & Denmark & Sweden & Finland & Total \\
\hline Morning (6.00 to 12.00) & 8 & 21 & 12 & 12 \\
\hline Afternoon (12.00 to 18.00) & 19 & 10 & 33 & 22 \\
\hline Evening (18.00 to 24.00) & $\mathbf{5 4}$ & $\mathbf{5 7}$ & $\mathbf{3 6}$ & $\mathbf{4 7}$ \\
\hline Night (00.00 to 6.00) & 20 & 13 & 19 & 18 \\
\hline Total & 100 & 100 & 100 & 100 \\
\hline $\mathrm{N}<.01$ & 91 & 63 & 103 & 257 \\
\hline
\end{tabular}

Table 2 Homicide incidents by weekday (\%), Nordic countries 1608-1699.

\begin{tabular}{|r|c|c|c|c|}
\hline & Denmark & Sweden & Finland & Total \\
\hline Monday & 16 & 20 & 8 & 15 \\
\hline Tuesday & 13 & 13 & 11 & 13 \\
\hline Wednesday & 17 & 11 & 14 & 15 \\
\hline Thursday & 13 & 13 & 13 & 13 \\
\hline Friday & 7 & 4 & 13 & 7 \\
\hline Saturday & 9 & 17 & $\mathbf{2 2}$ & 14 \\
\hline Sunday & $\mathbf{2 5}$ & $\mathbf{2 3}$ & 19 & $\mathbf{2 3}$ \\
\hline Total & 100 & 100 & 100 & 100 \\
\hline ns & 166 & 71 & 63 & 300 \\
\hline
\end{tabular}
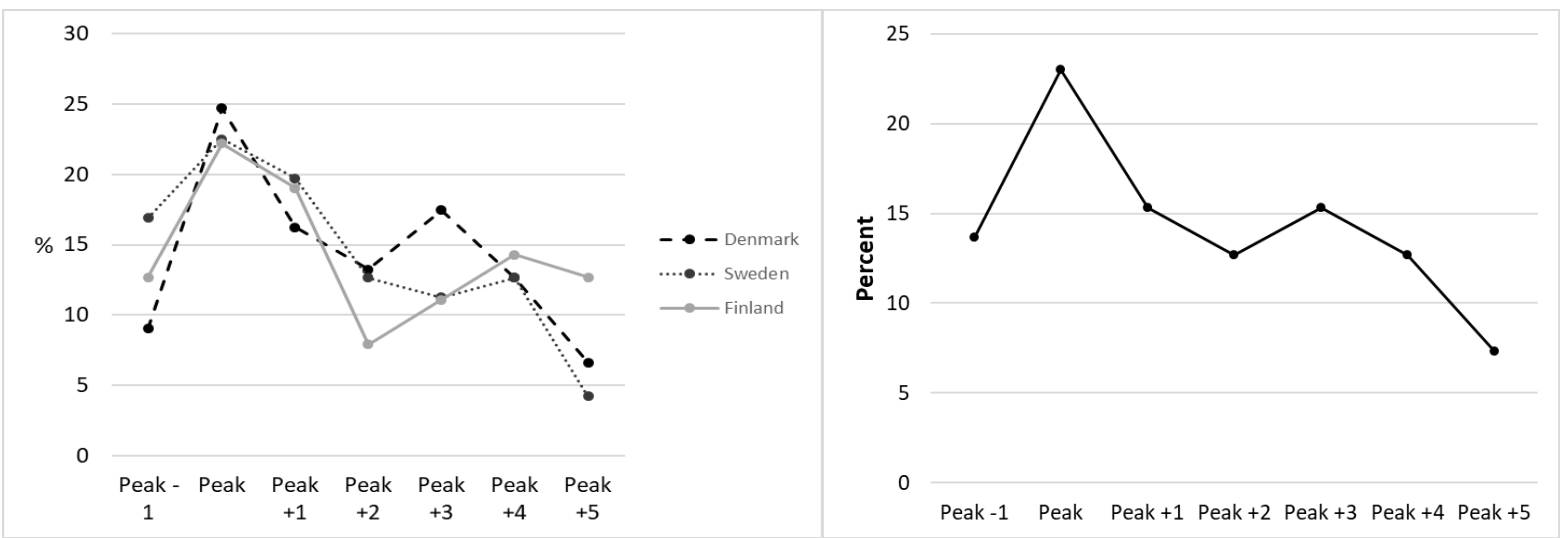

Figure 1 Homicide incidents by weekday (\%), in relation to the peak homicide day, by study region and total data. Nordic countries 1608-1699. $\mathrm{N}=300$. 

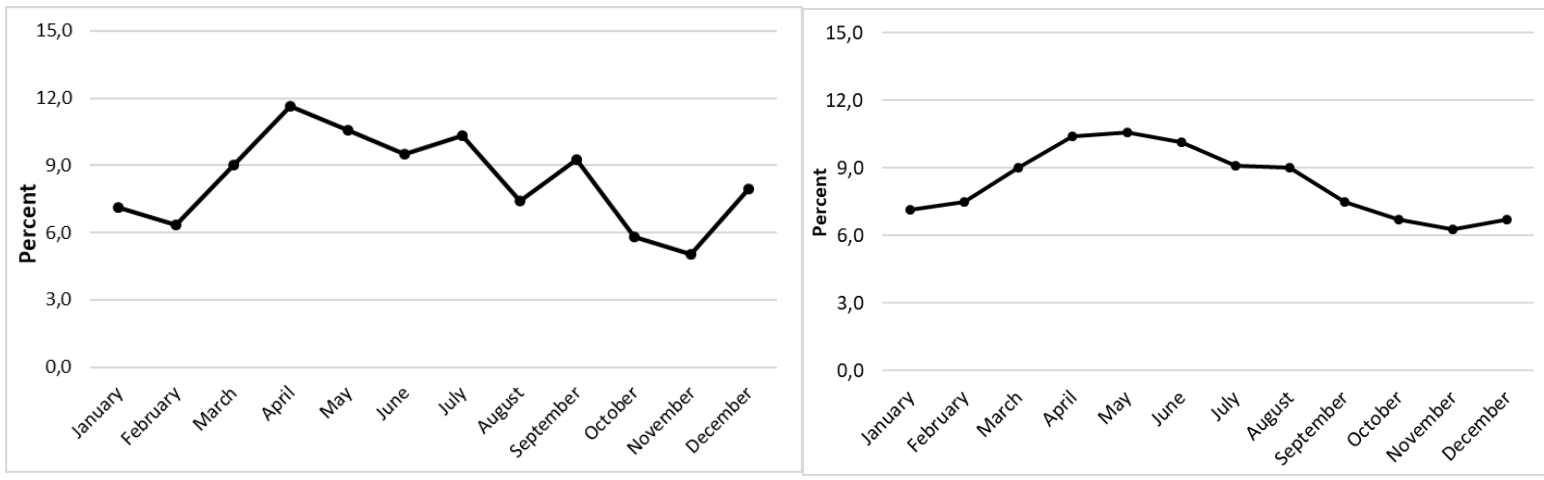

Figure 2 Homicide incidents by month (\%), aggregated Nordic countries 1608-1698. The raw distribution (left) and a smoothed distribution based on three-month moving averages (right). $\mathrm{N}=378$.

Table 3 Homicide incidents by month (\%), by country, 1608-1698.

\begin{tabular}{|r|c|c|c|c|}
\hline & Denmark & Sweden & Finland & Total \\
\hline January & 8 & 8 & 5 & 7 \\
\hline February & 8 & 7 & 4 & 6 \\
\hline March & 6 & 7 & 15 & 9 \\
\hline April & 12 & 13 & 10 & 12 \\
\hline May & 13 & 6 & 10 & 11 \\
\hline June & 9 & 15 & 6 & 10 \\
\hline July & 14 & 7 & 7 & 10 \\
\hline August & 9 & 5 & 6 & 7 \\
\hline September & 9 & 7 & 12 & 9 \\
\hline October & 6 & 4 & 6 & 6 \\
\hline November & 2 & 6 & 8 & 5 \\
\hline December & 5 & 13 & 9 & 8 \\
\hline Total & 100 & 100 & 100 & 100 \\
\hline $\mathrm{N}$ & 173 & 95 & 110 & 378 \\
\hline p $<.05 \quad$ & & & & \\
\hline
\end{tabular}

Table 4 Homicide incidents by season ${ }^{\mathrm{a}}$ (\%), Nordic countries 1608-1699.

\begin{tabular}{|c|c|c|c|c|}
\hline & Denmark & Sweden & Finland & Total \\
\hline Winter $^{a}$ & 19 & 27 & 21 & 22 \\
\hline Spring $^{\mathrm{b}}$ & 32 & 28 & 34 & 32 \\
\hline Summer ${ }^{c}$ & 32 & 27 & 17 & 25 \\
\hline Autumn $^{d}$ & 18 & 19 & 28 & 21 \\
\hline Total & 100 & 100 & 100 & 100 \\
\hline$N$ & 177 & 113 & 157 & 447 \\
\hline$p<.05$ & & & & \\
\hline
\end{tabular}


Table 5 Offenders under influence of alcohol and incidents in private places by timing of offence, \% of Nordic homicide 1608-1699.

\begin{tabular}{|c|c|c|c|c|c|}
\hline & & $\begin{array}{c}\text { Offender under } \\
\text { alcohol influence }^{a}\end{array}$ & $(\mathrm{~N})$ & Private place $^{b}$ & $(\mathrm{~N})$ \\
\hline \multirow[t]{5}{*}{ Time of day } & Morning & 16 & $(38)$ & 60 & $(30)$ \\
\hline & Afternoon & 27 & $(60)$ & 42 & $(55)$ \\
\hline & Evening & 67 & $(148)$ & 65 & (113) \\
\hline & Night & 39 & (56) & 54 & $(41)$ \\
\hline & & & \multicolumn{2}{|l|}{$(302)^{* *}$} & $(239)^{*}$ \\
\hline \multirow[t]{3}{*}{ Public holiday } & No & 37 & $(297)$ & 52 & $(252)$ \\
\hline & Yes & 68 & ( & 59 & $(65)$ \\
\hline & & & \multicolumn{2}{|l|}{$(395)^{* *}$} & $(317)$ \\
\hline \multirow[t]{8}{*}{ Weekday } & Mon & 74 & (49) & 75 & $(40)$ \\
\hline & Tue & 40 & $(40)$ & 38 & (37) \\
\hline & Wed & 33 & (46) & 49 & (45) \\
\hline & Thu & 40 & $(43)$ & 47 & (36) \\
\hline & Fri & 26 & (19) & 47 & (19) \\
\hline & Sat & 36 & (58) & 47 & (38) \\
\hline & Sun & 62 & (93) & 59 & $(66)$ \\
\hline & & & $(348)^{*}$ & & $(281)^{*}$ \\
\hline \multirow[t]{13}{*}{ Month } & Jan & 70 & (30) & 67 & (24) \\
\hline & Feb & 41 & $(27)$ & 55 & $(22)$ \\
\hline & Mar & 44 & (34) & 55 & (33) \\
\hline & Apr & 52 & $(50)$ & 55 & $(42)$ \\
\hline & May & 54 & (54) & 56 & $(36)$ \\
\hline & Jun & 54 & (41) & 39 & (31) \\
\hline & Jul & 27 & (37) & 52 & (31) \\
\hline & Aug & 35 & (37) & 33 & $(27)$ \\
\hline & Sep & 16 & $(37)$ & 46 & (35) \\
\hline & Oct & 19 & $(27)$ & 43 & $(21)$ \\
\hline & Nov & 63 & $(24)$ & 69 & (16) \\
\hline & Dec & 49 & $(35)$ & 59 & (27) \\
\hline & & & \multicolumn{2}{|l|}{$(433) * *$} & $(345)$ \\
\hline \multirow[t]{8}{*}{ Season } & Winter & 52 & $(108)$ & 58 & (85) \\
\hline & Spring & 48 & (159) & 50 & (133) \\
\hline & Summer & 37 & $(124)$ & 42 & $(97)$ \\
\hline & Autumn & 28 & (107) & 48 & (87) \\
\hline & & & \multicolumn{2}{|l|}{$(498)^{* *}$} & $(402)$ \\
\hline & Total & 41 & $(567)$ & 49 & $(456)$ \\
\hline & \multicolumn{2}{|c|}{$a=$ Offenders $b=$ Incidents } & & & \\
\hline & \multicolumn{2}{|c|}{$*=p<.05^{* *}=p<.01$} & & & \\
\hline
\end{tabular}




\footnotetext{
${ }^{1}$ Regarding the legal and political context of the early modern period in the Nordic area, see Netterstrøm 2017 and Pihlajamäki 2018.

2 Data sampling and coding was conducted by Jeppe Büchert Netterstrøm (Denmark), Mona Rautelin (Finland) and Dag Lindström (Sweden). Icelandic data from the years 1900-1989 is not included in this article.

${ }^{3}$ This excludes claims of causing death through supernatural means such as sorcery, curses, spells, etc.

${ }^{4}$ Infanticide is usually studied separately from other homicide types, partly because general criminological theories on homicide are difficult to adapt to the practice of homicidal or selective lethal neglect of infants shortly after birth. Especially in neonaticides, factors related to pregnancy and childbirth such as the mother's mental problems during pregnancy, play an important role. An added reason is the low and variable detection rate of infanticide especially in historical periods (Jackson 2006; Rautelin 2009; 2015; Porter \& Gavin 2010; Ellonen et al. 2015).

${ }^{5}$ In the relevant period, the Julian calendar was still applied in the Nordic region. The Gregorian calendar replaced it in Denmark in 1700 and in Finland and Sweden in 1753. Since date transformations algorithms in statistical software can overlook local and national differences in the calendar transition, we made extensive checks from edited historical calendars.

${ }^{6}$ Significance in Table 1 and other analyses refers to chisq test.

${ }^{7}$ In Denmark and Sweden, Sunday, in Finland, Saturday. Interestingly, there appears to be a secondary peak in Wednesday, reflecting Danish and Finnish cycles.

${ }^{8}$ The weekly low on Fridays in both Denmark and Sweden remains an unsolved issue at this point.

${ }^{9}$ Here we ignore the differential duration of months.

${ }^{10} \mathrm{~N}=340$, ns.

${ }^{11} \mathrm{~N}=337, \mathrm{p}<.01$.

${ }^{12}$ Private homes refer to buildings used for living in farms or villages, in predominantly rural settings. In the early modern period, the "home" was not as private area as it is today.

${ }^{13}$ We checked if missing timing data were more prevalent in sub-groups defined by victim gender, location of offence, offender alcohol use, and familial vs. other homicide. Generally, the likelihood of data loss was not biased in these dimensions. However, we observed that the weekday variable had more missing data in crimes against females, and in familial/kin homicide. The time of day variable had more missing data in incidents taking place in public locations. Cases with offenders under the influence of alcohol had less missing timing data than other cases, possibly because drunkenness was often linked to specific public holidays. The data may thus exaggerate the drunkenness-public holiday link.
} 